\title{
Priming Uygulamalarının Kadmiyum ve Nikel Stresine Maruz Bırakılan Kırmızı Yumağın Çimlenme ve Fide Gelişimi Üzerine Etkisi
}

\author{
The Effects of Priming Treatments on Germination and Seedling Growth of Red Fescue \\ under Nickel and Cadmium Stress
}

\author{
Melek AKAR ${ }^{1, a}$, İbrahim ATIŞ ${ }^{2, b}$ \\ ${ }^{1}$ Mustafa Kemal Üniversitesi, Fen Bilimleri Enstitüsü, Tarla Bitkileri ABD, 31060, Antakya/Hatay \\ ${ }^{2}$ Mustafa Kemal Üniversitesi, Ziraat Fakültesi, Tarla Bitkileri Bölümü, 31060, Antakya/Hatay
}

• Geliş tarihi / Received: 29.01.2018 • Düzeltilerek geliş tarihi / Received in revised form: 17.04.2018 • Kabul tarihi / Accepted: 08.06.2018

\begin{abstract}
$\ddot{O} z$
$\mathrm{Bu}$ çalışma kırmızı yumakta farklı dozlarda kadmiyum $(\mathrm{Cd})$ ve nikele $(\mathrm{Ni})$ maruz bırakılan tohumlarda farklı priming uygulamalarının çimlenme ve fide gelişimi üzerine etkilerini belirlemek amacıyla laboratuvar koşullarında yürütülmüştür. Araştırmada bu iki ağır metalin farklı konsantrasyonları $\left(0,75,150,300 \mathrm{mg} \mathrm{l}^{-1}\right)$ kullanılmıştır. Ağır metal uygulamaları altında priming uygulamalarının çimlenmeye etkisini belirlemek amacıyla \% 2'lik $\mathrm{KNO}_{3}$ ve 500 ppm $\mathrm{GA}_{3}$ uyarıcı ajanı olarak kullanılmıştır. Araştırma tesadüf parsellerinde faktöriyel deneme desenine göre 4 tekrarlamalı olarak kurulmuş ve yürütülmüştür. Araştırma sonucunda her iki ağır metalin de kırmızı yumağın çimlenme ve fide özellikleri üzerinde olumsuz etkiye neden olduğu, çimlenme özellikleri üzerine ağır metallerin etkisini azaltmada priming uygulamalarının etkisiz kaldığı, hatta yüksek ağır metal dozlarında çimlenmenin priming uygulamalarından negatif yönde etkilendiği görülmüştür. Kırmızı yumağın kök uzunluğu üzerinde priming uygulamalarının olumlu bir etkisi olmazken, fide gelişimi $\mathrm{GA}_{3}$ uygulaması ile olumlu yönde etkilenmiștir. Ayrıca kırmızı yumağın çimlenme özellikleri ve fide gelişimi üzerinde nikelin olumsuz etkilerinin kadmiyumdan daha yüksek olduğu belirlenmiştir.
\end{abstract}

Anahtar kelimeler: Çimlenme, Kadmiyum, Kırmızı Yumak, Nikel, Stres

\begin{abstract}
The objectives of this study were to determine effects of different priming treatments on germination and seedling growth in red fescue infected with different levels $\left(0,75,150\right.$ and $\left.300 \mathrm{mg} \mathrm{l}^{-1}\right)$ of cadmium and nickel. The study was conducted under laboratory conditions. In the study, two heavy metal kinds (Cadmium (Cd) and Nickel (Ni)) were considered 3 different concentrations $\left(75,150,300 \mathrm{mg} \mathrm{l}^{-1}\right)$ and distillate water as control application. To determine the effect of germination priming under heavy metal stress, $2 \% \mathrm{KNO}_{3}$ and $500 \mathrm{ppm} \mathrm{GA}_{3}$ were used as priming agents. The research was performed as factorial arrangement of completely randomized design with four replications. The results of study indicated that both germination and seedling growth properties were negatively affected by both heavy metal kinds. Priming treatments were ineffective in reducing the effects of heavy metals on germination properties. Germination at high doses of heavy metals was negatively affected by priming treatments. There wasn't positively effect on root length of red fescue of priming treatments, while shoot length was positively affected by GA3 treatment. Also, the negatively effects on germination and seedling growth of nickel were greater than cadmium.
\end{abstract}

Keywords: Germination, Cadmium, Red Fescue, Nickel, Stress

\footnotetext{
*b İbrahim ATIŞ; iatis15@hotmail.com; Tel: (0544) 79904 07; orcid.org/0000-0002-0510-9625

${ }^{a}$ orcid.org/0000-0001-9799-5857
} 


\section{Giriş}

Toprak, su ve havada değişik oranlarda bulunabilen ve belirli konsantrasyonun üzerinde kirliliğe yol açan ağır metaller bitki üzerinde olumsuz etkilere yol açan önemli abiyotik stres etmenlerinin başında gelmektedir. Maruz kalınan bu stres koşulları ise bitkilerin fizyolojisini etkiler, onların genetik potansiyellerini değiştirir ve ölümlerine yol açarak büyük oranlarda ürün kayıpları meydana getirir (Kırbağ-Zengin ve Munzuroğlu, 2003). Ağır metallerin bitkiler üzerinde etkilerini araştırmak üzere yürütülen araştırmaların çoğu, bitkilerin ağır metallere toleransını ve bitkiler tarafindan alınabilen (topraktan uzaklaştırılan) miktarlarını belirlemek amacıyla yetişkin veya halihazırda çimlenmiş fideler üzerinde yapılmıştır (Peralta vd., 2001). Ancak, çimlenmeyi başaramayan bitkilerin fide ve olgun bitki haline gelemeyeceği bir gerçektir. Bu nedenle bitki türlerinin çimlenme ortamında var olan ağır metallerin çimlenme ve fide oluşturma yeteneği üzerine etkisinin bilinmesi bu noktada oldukça önemlidir.

Ağır metaller içerisinde 20 kadar element ekolojik açıdan dikkati çekmekte ( $\mathrm{Fe}, \mathrm{Mn}, \mathrm{Zn}, \mathrm{Cu}, \mathrm{V}, \mathrm{Mo}$, $\mathrm{Co}, \mathrm{Ni}, \mathrm{Cr}, \mathrm{Pb}, \mathrm{Be}, \mathrm{Cd}, \mathrm{Tl}, \mathrm{Sb}, \mathrm{Se}, \mathrm{Sn}, \mathrm{Ag}, \mathrm{As}$, $\mathrm{Hg}, \mathrm{Al}$ ) ve bunların bir kısmı, bitki ve hayvanlar için mikrobesin $(\mathrm{Fe}, \mathrm{Cu}, \mathrm{Zn}, \mathrm{Mn}, \mathrm{Mo}, \mathrm{Ni})$ maddesi olabilmekte ve belirli sınırı aşmadığ sürece toksik olmamaktadırlar (Okcu vd., 2009). Bunlardan Kadmiyum (Cd), günümüzde çeşitli kullanım alanlarıyla ve çevre kirliliğindeki olumsuz etkileri ile gündeme gelmiş oldukça toksik bir metaldir. Kadmiyumun son zamanlarda bir kirletici olarak bu denli gündemde olmasının temel nedeni çok düşük dozlarda bile toksik olması ve biyolojik yarı ömrünün uzun olmasıdır (Goyer, 1991; Lyons-Alcantara vd., 1996; Okcu vd., 2009).

Kadmiyumun bitkilerin çimlenmesi ve fide gelişimi üzerine etkilerini belirlemek üzere farklı bitki türleri ile yapılan araştırma sonuçları bitkilerin artan kadmiyum dozlarından olumsuz etkilendiği ancak türlerin kadmiyuma tolerans eşiklerinin farklılık gösterdiğini ortaya koymaktadır (Peralta vd., 2001; Kabir vd., 2008; Muhammad vd., 2008; Houshmandfar ve Moragebi, 2011; Smiri, 2011).

Ağır metaller içerisinde nikelin (Ni) düşük dozlarda bitki için gerekli iken, artan endüstriyel faaliyetler, mineral ve organik gübreler, kimyasal ilaçlar ile yerleşim yeri ve endüstri atıkları nedeniyle ekolojik çevrede miktarının arttığ 1
(Zornoza vd., 1999), bunun sonucunda aşırı konsantrasyonlarının bitkilerde olumsuz etkilerinin olduğu bilinmektedir (Erdoğan, 2005). Nikelin yüksek dozları, bitkilerde çimlenme aşamasından başlayarak bitkinin büyüme ve gelişmesinde toksik etki yapmaktadır (Marschner, 1995).

Bitki türlerin farklı stres koşullarına gösterdikleri tepkiler birbirinden farklıdır ve bu tepkilerin ayrı ayrı ortaya konulması gerekmektedir. Stres koşullarının varlığında çimlenmenin sorunsuz bir şekilde gerçekleşmesinde ekim öncesi tohum priming uygulamaları başarı sonuçlar verebilmektedir. Priming, bir örnek çimlenme, çimlenmenin ve çıkışın teşvikinde ticari olarak da kabul görmüş tohum uygulamalarının genel adıdır. Priming uygulamalarında $\mathrm{KNO}_{3}, \mathrm{PEG}$, $\mathrm{CuSO}_{4}$ ve $\mathrm{GA}_{3}$ gibi farklı priming ajanları kullanılmaktadır (Mavi vd., 2006; Mavi vd., 2010; Patade vd., 2011). Günümüzde, tohum priming uygulamaları ile tohum ekimi ve fide çıkışı arasındaki dönemde karşılaşılan problemler azaltılabilmekte, çıkış süresi kısaltılabilmekte, uniform fide çıkış1 sağlanabilmekte, düşük ve yüksek sıcaklık, termodormansi (Sung vd., 1998), tuzluluk gibi çeşitli abiyotik stres koşullarının çimlenme üzerine olumsuz etkileri azaltılabilmektedir (Khan, 1992).

Yeşil alan buğdaygilleri çevre koruma ve kirliliğin azaltılması bakımından büyük öneme sahiptir. $\mathrm{Bu}$ bitkiler güçlü rejenerasyon yeteneği, hızlı büyüme ve gelişme ve yıl içerisinde çok sayıda biçilme gibi özelliklere sahiptirler. Özellikle bu bitkilerin besin zincirine girmeksizin, yıl içerisinde çok sayıda yapılan biçimlerle ortamda bulunan ağır metallerin uzaklaştırılması sağlanabilmektedir (Duo vd., 2005). Kırmız1 yumak ((Festuca rubra L. subsp. rubra) yeşil alanların oluşturulmasında en fazla kullanılan serin mevsim buğdaygil bitkilerinin başında gelmektedir (Açıkgöz, 1994; Avc1oğlu, 1997).

$\mathrm{Bu}$ çalışmada yeşil alan tesisinde yoğun olarak kullanılan kırmızı yumakta tohumların maruz bırakıldığı faklı dozlardaki iki ağır metalin (nikel ve kadmiyum) çimlenme özelliklerine etkisinin belirlenmesi ve bu stres koşulları altında çimlenmenin teşvik edilmesi amacıyla priming materyali olarak kullanılan $\mathrm{KNO}_{3}$ ve $\mathrm{GA}_{3}$ 'ün etkilerinin tespiti amaçlanmıştır.

\section{Materyal ve Yöntem}

Çalışmada, iki ağır metalin (kadmiyum ve nikel) farklı konsantrasyonları $\left(0,75,150,300 \mathrm{mg} \mathrm{l}^{-1}\right)$ 
dikkate alınmıştır. Ağır metale maruz bırakılan tohumlara priming uygulamalarının çimlenmeye etkisini belirlemek amaciyla \%2'lik $\mathrm{KNO}_{3}$ ve 500 ppm $\mathrm{GA}_{3}$ priming ajanı olarak kullanılmıştır.

Priming uygulaması, tohumlar ekilmeden önce yüzey sterilizasyonu (\% 1'lik sodyum hipoklorit çözeltisi ile 10 dakika) uygulanan tohumların belirtilen dozlarda hazırlanan $\mathrm{KNO}_{3}$ ve $\mathrm{GA}_{3}$ çözeltilerinde 2 gün (48 saat) süreyle $25^{\circ} \mathrm{C}^{\prime}$ de bekletilmesi şeklinde uygulanmıştır. Ayrıca uyarıc1 uygulaması yapılmayan bir grup kontrol amaciyla sterilizasyon sonrası 48 saat uyarıcı uygulamaları ile aynı koşullarda saf suda (Hydropriming) bekletildikten sonra ekimi yapılmak üzere hazırlanmıştır. Gerekli ön muameleler uygulanan türlere ait tohumlar, $9 \mathrm{~cm}$ çapındaki petri kapları içine iki kat olarak yerleştirilen filtre kâğıdı üzerine, her petriye 25 tohum gelecek şekilde yerleştirilmiştir.

Kadmiyum ve nikelin $75,150,300 \mathrm{mg} \mathrm{l}^{-}$ ${ }^{1}$ dozlarında hazırlanan stok çözeltisinden ve kontrol uygulamaları için saf sudan $10 \mathrm{ml}$ ilave edilmiştir. Su kaybını önlemek için kenarları parafilmle kapatılan, petri kapları, $25 \pm 1{ }^{\circ} \mathrm{C}$ sıcaklığa ayarlı iklim dolabına yerleştirilmiştir. Denemede çimlenme sayımları 14. güne kadar yapılmış olup, 14. günde her petride çimlenen 10 bitkide fide ölçümleri yapılmıştır.

Çimlenme oranı (ÇO) (Akıncı ve Çalışkan, 2010), Çimlenme indeksi (Çİ) (Wang vd., 2004) ve ortalama çimlenme süresi (OÇS) (Ellis ve Roberts, 1980) değerleri aşağıdaki formüllere göre hesaplanmıştır.

ÇO $(\%)=($ Çimlenen tohum sayısı / Toplam tohum say1s1) $\times 100$,

Çİ $=\sum(\mathrm{Gi} / \mathrm{Tt})$
Gi: i. günde çimlenen tohum oran1; Tt: Sayım günü,

$\mathrm{OÇS}=\Sigma(\mathrm{fx}) / \Sigma \mathrm{f}$

f: Çimlenen tohum sayısı; x: Çimlenme günü

Araştırmada elde edilen verilere MSTAT-C istatistik paket programı kullanılarak tesadüf parsellerinde faktöriyel deneme desenine uygun olarak varyans analizi uygulanmıştır. Varyans analizi sonuçlarına göre istatistiksel olarak önemli çıkan faktör ortalamaları Duncan testi ile gruplandırılmıştır.

\section{Bulgular ve Tartışma}

\section{1. Çimlenme Oranı}

Kırmızı yumakta farklı metal türü, metal dozu ve priming uygulamaları altında belirlenen çimlenme oranı değerlerine uygulanan varyans analiz sonuçları, çimlenme oranı üzerine metal türü, metal dozu, priming, metal türü $\mathrm{x}$ metal dozu ve metal dozu x priming ikili interaksiyonlarının $\% 1$ düzeyinde önemli etkiye sahip olduğunu göstermiştir. Metal türü $\mathrm{x}$ priming ikili interaksiyonu ile deneme faktörlerinin üçlü interaksiyonunun çimlenme oranı üzerindeki etkisi ise istatistiksel olarak önemsiz olmuştur (Tablo 1).

Deneme sonuçları, ağır metal türüne bağlı olarak çimlenme oranlarının önemli farklılık gösterdiğini, kadmiyum stresi altında kırmızı yumağın çimlenme oranının (\% 64.31) nikel uygulamasi altındaki bitkilerde belirlenen çimlenme oranından (\% 52.36) önemli derecede yüksek olduğunu göstermiş̧tir (Tablo 2). Nitekim Peralta-Videa vd. (2004) ve Houshmandfar ve Moraghebi (2010) nikelin bitki fideleri üzerindeki ölümcül etkilerinin kadmiyumdan daha fazla olduğunu bildirmişlerdir.

Tablo 1. İncelenen özelliklere ait kareler ortalamaları ve deneme faktörlerin istatistiksel önemlilikleri

\begin{tabular}{|c|c|c|c|c|c|c|}
\hline \multirow[b]{2}{*}{ Varyasyon Kaynağı } & \multirow[b]{2}{*}{ SD } & \multicolumn{5}{|c|}{ Kareler Ortalaması } \\
\hline & & $\begin{array}{c}\text { Çimlenme Oranı } \\
(\%)\end{array}$ & $\begin{array}{l}\text { Çimlenme } \\
\text { İndeksi }\end{array}$ & $\begin{array}{c}\text { Ortalama } \\
\text { Çimlenme Süresi } \\
\text { (gün) }\end{array}$ & $\begin{array}{c}\text { Kök } \\
\text { Uzunluğu } \\
(\mathbf{m m})\end{array}$ & $\begin{array}{c}\text { Fide } \\
\text { Uzunluğu } \\
(\mathbf{m m})\end{array}$ \\
\hline Ağır Metal Türü (A) & 1 & $3424.751 * *$ & $31.293 * *$ & $13.380 * *$ & $32.202 * *$ & 24.311 \\
\hline Ağır Metal Dozu (B) & 3 & $3830.616 * *$ & $22.439 * *$ & $7.772 * *$ & $266.318 * *$ & $1054.019 * *$ \\
\hline A X B & 3 & $988.403 * *$ & $6.660 * *$ & 1.554 & $17.720 * *$ & 4.699 \\
\hline Priming $(\mathrm{C})$ & 2 & $1043.321 * *$ & $9.532 * *$ & $5.379 * *$ & 0.985 & $1517.515^{* *}$ \\
\hline $\mathrm{A} \times \mathrm{C}$ & 2 & 75.452 & 1.380 & 0.875 & 1.103 & 13.716 \\
\hline B X C & 6 & $549.869 * *$ & $1.865 *$ & 0.966 & $8.780 * *$ & 37.274 \\
\hline A X B X C & 6 & 174.869 & 0.946 & 0.447 & 2.670 & 46.946 \\
\hline Hata & 72 & 140.428 & 0.714 & 0.896 & 1.804 & 23.383 \\
\hline
\end{tabular}

* 0.05 hata sınırları içerisinde önemli, ** 0.01 hata sınırları içerisinde önemli 
Ağır metal dozlarındaki artışa bağlı olarak çimlenme oranları önemli farklılık göstermiştir. Artan dozlara bağli olarak $\left(0,75,150\right.$ ve $300 \mathrm{mg} \mathrm{l}^{-}$ ${ }^{1}$ için sırasıyla) çimlenme oranları \% 73.33, \% 63.06, \% 52.78 ve \% 44.17 olarak belirlenmiştir. Artan doza bağlı olarak sürekli bir düşüş meydana gelmiş ve her bir ağır metal dozu için belirlenen ortalama çimlenme oranı değeri istatistiksel olarak farklı bir grupta yer almıştır (Tablo 2). Çimlenme oranı, artan ağır metal dozlarına göre sirasıyla kontrole göre $\% 14, \% 21$ ve $\% 40$ oranında azalmıştır. Ortamda ağır metallerin bulunmasının ve artan dozlarda bitkilerin çimlenmeleri üzerindeki olumsuz etkinin arttığ diğer araştırıcılar tarafından da bildirilmiştir (Çalışkan, 2009; Kabir vd., 2008; Housmandfar ve Moraghebi, 2011).

Priming uygulamalarının çimlenme oranı üzerine etkileri incelendiğinde, hydropriming uygulamasında belirlenen çimlenme oranı $\mathrm{GA}_{3}$ ve $\mathrm{KNO}_{3}$ ile ön muameleye tabi tutulan tohumlardan daha yüksek olmuştur. Saf suda bekletilen tohumlarda ortalama çimlenme oranı $\% 64.79$ olurken, $\mathrm{GA}_{3}$ ve $\mathrm{KNO}_{3}$ uygulamasinda ise çimlenme oranları sirasıyla \% 56.25 ve 53.96 olarak belirlenmiştir (Tablo 2). Bu durum ağır metallerle birlikte ortamda bulunan priming ajanlarının olumsuz etkide de bulunabileceğini göstermektedir. Çimlenme oranı değerlerine uygulanan varyans analizi sonuçları çimlenme oranı üzerine metal türü $\mathrm{x}$ metal dozu ikili interaksiyonunun etkisinin önemli olduğunu göstermiştir (Tablo 1). Her iki metal türünde de artan dozlara bağlı olarak kırmızı yumağın çimlenme oranı önemli derecede azalma eğilimi göstermiştir. Ancak bu azalma, nikelle bulaşık ortamda bulunan bitkilerin çimlenme oranında daha şiddetli olmuştur.

Tablo 2. Ağır metal türü, ağır metal dozu ve priming uygulamalarının çimlenme oranı, çimlenme indeksi, ortalama çimlenme zamanı, kök uzunluğu ve fide uzunluğu üzerine etkileri

\begin{tabular}{|c|c|c|c|c|c|}
\hline & $\begin{array}{c}\text { Çimlenme } \\
\text { Oranı } \\
(\%)\end{array}$ & $\begin{array}{c}\text { Çimlenme } \\
\text { İndeksi }\end{array}$ & $\begin{array}{c}\text { Ortalama Çimlenme } \\
\text { Süresi } \\
\text { (gün) }\end{array}$ & $\begin{array}{c}\text { Kök } \\
\text { Uzunluğu } \\
(\mathbf{m m})\end{array}$ & $\begin{array}{c}\text { Fide } \\
\text { Uzunluğu } \\
(\mathbf{m m})\end{array}$ \\
\hline \multicolumn{6}{|c|}{ Ă̆gr Metal Türü * } \\
\hline Kadmiyum & $64.31 \mathrm{a}^{*}$ & $3.34 \mathrm{a}$ & $3.41 \mathrm{~b}$ & $5.79 \mathrm{a}$ & 25.46 \\
\hline Nikel & $52.36 \mathrm{~b}$ & $2.19 \mathrm{~b}$ & $4.15 \mathrm{a}$ & $4.63 \mathrm{~b}$ & 24.25 \\
\hline \multicolumn{6}{|c|}{ Ağır Metal Dozu ** } \\
\hline $0 \mathrm{mg} \mathrm{l}^{-1}$ & $73.33 \mathrm{a}^{* *}$ & $4.21 \mathrm{a}$ & $3.07 \mathrm{c}$ & $10.05 \mathrm{a}$ & $32.57 \mathrm{a}$ \\
\hline $75 \mathrm{mg} \mathrm{l}^{-1}$ & $63.06 \mathrm{~b}$ & $2.36 \mathrm{~b}$ & $3.70 \mathrm{~b}$ & $4.71 \mathrm{~b}$ & $27.43 \mathrm{~b}$ \\
\hline $150 \mathrm{mg} \mathrm{l}^{-1}$ & $52.78 \mathrm{c}$ & $2.34 \mathrm{~b}$ & $4.45 \mathrm{a}$ & $3.33 \mathrm{c}$ & $22.79 \mathrm{c}$ \\
\hline $300 \mathrm{mg} \mathrm{l}^{-1}$ & $44.17 \mathrm{~d}$ & $2.14 \mathrm{~b}$ & $3.92 \mathrm{ab}$ & $2.74 \mathrm{c}$ & $17.03 \mathrm{~d}$ \\
\hline \multicolumn{6}{|l|}{ Priming $* * *$} \\
\hline Hydropriming & $64.74 \mathrm{a}^{* * * *}$ & $2.75 \mathrm{~b}$ & $3.88 \mathrm{a}$ & 5.15 & $19.07 \mathrm{c}$ \\
\hline $\mathrm{GA}_{3}$ & $56.25 \mathrm{~b}$ & $3.32 \mathrm{a}$ & $3.33 \mathrm{~b}$ & 5.07 & $32.53 \mathrm{a}$ \\
\hline $\mathrm{KNO}_{3}$ & $53.96 \mathrm{c}$ & $2.23 \mathrm{c}$ & $4.13 \mathrm{a}$ & 5.40 & $23.27 \mathrm{~b}$ \\
\hline
\end{tabular}

$*, * *, * * *$ Aynı sütun içerisinde farklı harfle gösterilen faktör ortalamaları istatistiksel olarak birbirinden farklıdır

Kadmiyum bulunan ortamdaki çimlenme oranları istatistiksel olarak kontrolden düşük olurken; kadmiyumun 75,150 ve $300 \mathrm{mg} \mathrm{l}^{-1}$ dozlarındaki çimlenme oranları istatistiksel olarak farksız olmuştur. Nikele maruz kalan bitkilerde ise kontrolden itibaren her doz arasında önemli azalmalar görülmüş ve her uygulama ayrı bir grupta yer almıştır (Şekil 1a). Bu durum kırmızı yumağın çimlenmesi üzerinde nikelin olumsuz etkilerinin kadmiyumdan daha yüksek olduğunu göstermiştir.

Çimlenme oranı değerlerine uygulanan varyans analiz sonuçları metal dozu $\mathrm{x}$ priming ikili interaksiyonun etkisinin \% 1 düzeyinde önemli etkiye sahip olduğunu göstermiştir (Tablo 1). Ağır metal uygulaması yapilmayan uygulamalar yüksek çimlenme oranlarına sahip olurken, ağır metal dozlarına ve teşvik edici ön uygulamalara bağlı olarak çimlenme oranları farklı eğilimler göstermiştir. Saf suda bekletilen tohumlarda ağır metale maruz kalan tohumların çimlenme oranı kontrolden düşük çıkmış; ağır metal dozları arasındaki farklılıklar ise istatistiksel olarak önemsiz bulunmuştur. $\mathrm{GA}_{3}$ ile ön muameleye tabi tutulan tohumlarda kontrol ve $75 \mathrm{mg} \mathrm{l}^{-1}$ uygulamalarında belirlenen çimlenme oranları aynı istatistiki grup içinde yer alırken; 150 ve 300 $\mathrm{mg} \mathrm{l}^{-1}$ ağır metal uygulamaları ise diğer grupta yer almıştır. $300 \mathrm{mg}^{-1}$ ağır metal dozu dikkate alındığında, $\mathrm{KNO}_{3}$ teşvik edici ön uygulamasına ait çimlenme oranları diğer teşvik edici uygulamalara göre önemli derecede düşük çıkmıştır (Şekil 1b). 

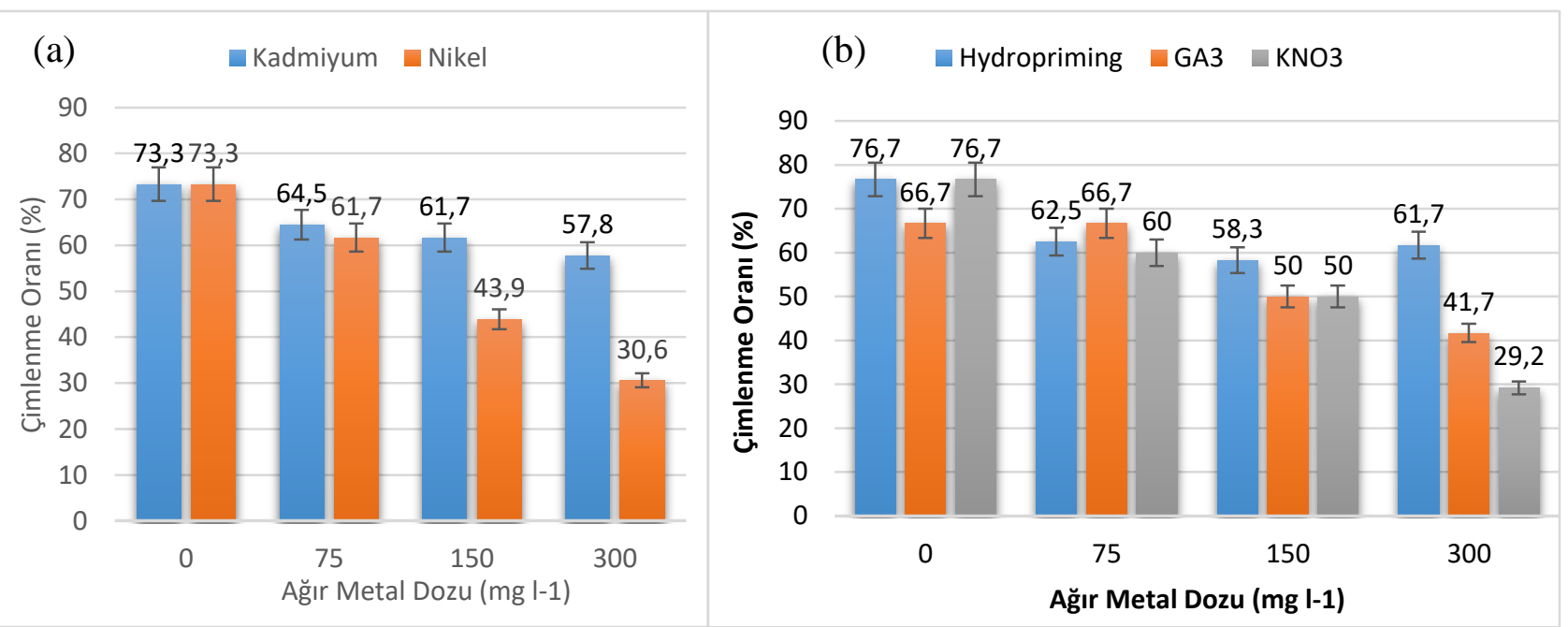

Şekil 1. Çimlenme oranı üzerine a) ağır metal türü $x$ ağır metal dozu ve b) ağır metal dozu x priming interaksiyonlarının etkisi.

\section{2. Çimlenme İndeksi}

Metal türlerine bağlı olarak çimlenme indeksinde önemli farklı1ıklar meydana gelmiştir (Tablo1). Kadmiyum stresi altındaki bitkilerde belirlenen çimlenme indeksi değeri 3.34 olurken, nikel stresi altındaki bitkilerde belirlenen çimlenme indeksi değeri 2.19 olarak tespit edilmiştir. Nitekim Çalışkan (2009), ağır metallerin çimlenme üzerindeki olumsuz etkilerinin metalin türüne ve dozuna bağlı olarak farklılık gösterebildiğini bildirmiştir.

Varyans analiz sonuçları metal dozlarının çimlenme indeksi üzerindeki etkisinin çok önemli olduğunu göstermiştir (Tablo 1). Bitkilerin ağır metale maruz kalması çimlenme indeksinde kontrole göre önemli bir azalmaya neden olmuştur. Kontrol uygulamasında 4.21 olan çimlenme indeksi değeri, 75, 150 ve $300 \mathrm{mg} \mathrm{l}^{-1}$ ağır metal dozları için sırasıyla 2.36, 2.34 ve 2.14 olarak belirlenmiştir. Ağır metal uygulanan tohumların çimlenme indeksi kontrolden daha yüksek ve kendi içinde birbirinden farksız çıkmıştır (Tablo 2). Ağır metale maruz kalan bitkilerin çimlenme indeksinde önemli azalmaların meydana geldiği Çalışkan (2009) ve Akınc1 ve Akınc1 (2011) tarafindan da bildirilmiştir.

Priming uygulamalarına bağlı olarak çimlenme indeksi değerleri 2.23 ile 3.32 arasında değişim göstermiştir (Tablo 2). Priming işlemlerinde $\mathrm{GA}_{3}$ uygulamasında belirlenen çimlenme indeksi değeri 3.32 ile ilk sırada yer alırken, bunu 2.75 ile hydropriming uygulaması takip etmiş ve $\mathrm{KNO}_{3}$ uygulamasında belirlenen çimlenme indeksi değeri 2.23 ile son sırada yer almıştır (Tablo 2).
Elde edilen sonuçlar çimlenmenin teşvik edilmesi açısından özellikle $\mathrm{GA}_{3}$ 'ün en iyi etkiyi gösterdiğini ortaya koymuştur. Espanany vd. (2016) benzer şekilde ağır metal varlığında farklı priming uygulamalarının etkisinin farklılık gösterdiğini bildirmişlerdir. Ayrıca priming ön uygulamalarında kullanılan priming ajanının dozu da çimlenme üzerindeki etkide belirleyici rol oynayabilmektedir (Sneideris vd., 2015).

Çimlenme indeksi üzerine metal türü $\mathrm{x}$ metal dozu interaksiyonun etkisi istatistiksel olarak önemli bulunmuştur (Tablo 1). Her iki metal türünde de ortamın ağır metalle bulaşık olması çimlenme indeksini önemli derecede azaltmış ve tüm ağır metal uygulaması içeren muamelelerde belirlenen çimlenme indeksi değerleri kontrole göre önemli derecede düşük olmuştur. Kadmiyuma maruz kalan tohumlarda belirlenen çimlenme indeksi değerleri kontrole göre önemli derecede düşük olurken, 75,150 ve $300 \mathrm{mg} \mathrm{l}^{-1}$ kadmiyum dozlarında belirlenen çimlenme indeksi değerleri istatistiksel olarak farksız bulunmuştur. Nikele maruz kalan tohumların çimlenme indeksleri değerlendirildiğinde, $\quad 300 \quad \mathrm{mg}^{-1} \quad$ dozunda belirlenen değer kontrol ve $75 \mathrm{mg} \mathrm{l}^{-1}$ dozlarında belirlenen değerden istatistiksel olarak önemli derecede düşük olurken; $150 \mathrm{mg} \mathrm{l}^{-1}$ dozu ile istatistiksel olarak farksız olmuştur (Şekil 2a).

Metal dozu $\mathrm{x}$ priming interaksiyonuna göre hesaplanan ortalama çimlenme indeksi değerleri ve oluşan gruplar Şekil 2b'de verilmiştir. Şekil 2b'de izlendiği gibi, kontrol ve $75 \mathrm{mg}^{-1}$ ağır metal dozunda $\mathrm{GA}_{3}$ priming uygulamasinda belirlenen çimlenme indeksi değeri diğer iki priming uygulamasında belirlenen değerden istatistiksel olarak yüksek olmuştur. Ağır metal 
dozunun 150 ve $300 \mathrm{mg} \mathrm{l}^{-1}$,ye çıkmasıyla priming uygulamaların etkileri farklılık göstermiştir. 150 $\mathrm{mg} \mathrm{l}^{-1}$ ağır metal dozunda hydropriming uygulamasında belirlenen değer $\mathrm{GA}_{3}$ uygulamasında belirlenen değerden daha yüksek olmuş, ancak bu farkl1lik istatistiksel olarak önemsiz olmuştur. $300 \mathrm{mg} \mathrm{l}^{-1}$ ağır metal dozunda ise $\mathrm{GA}_{3}$ uygulamasinda belirlenen değer hydropriming uygulamasında belirlenen değerden daha yüksek bulunmuştur. $\mathrm{KNO}_{3}$ priming uygulaması ise çimlenme indeksi değeri açısından ağır metal stresi bulunan tüm uygulamalarda en düşük değere sahip olmuştur. $\mathrm{Bu}$ durum yeterli çimlenme açısından $\mathrm{KNO}_{3}$ ile priming uygulamasının uygun olmadığını göstermiştir.
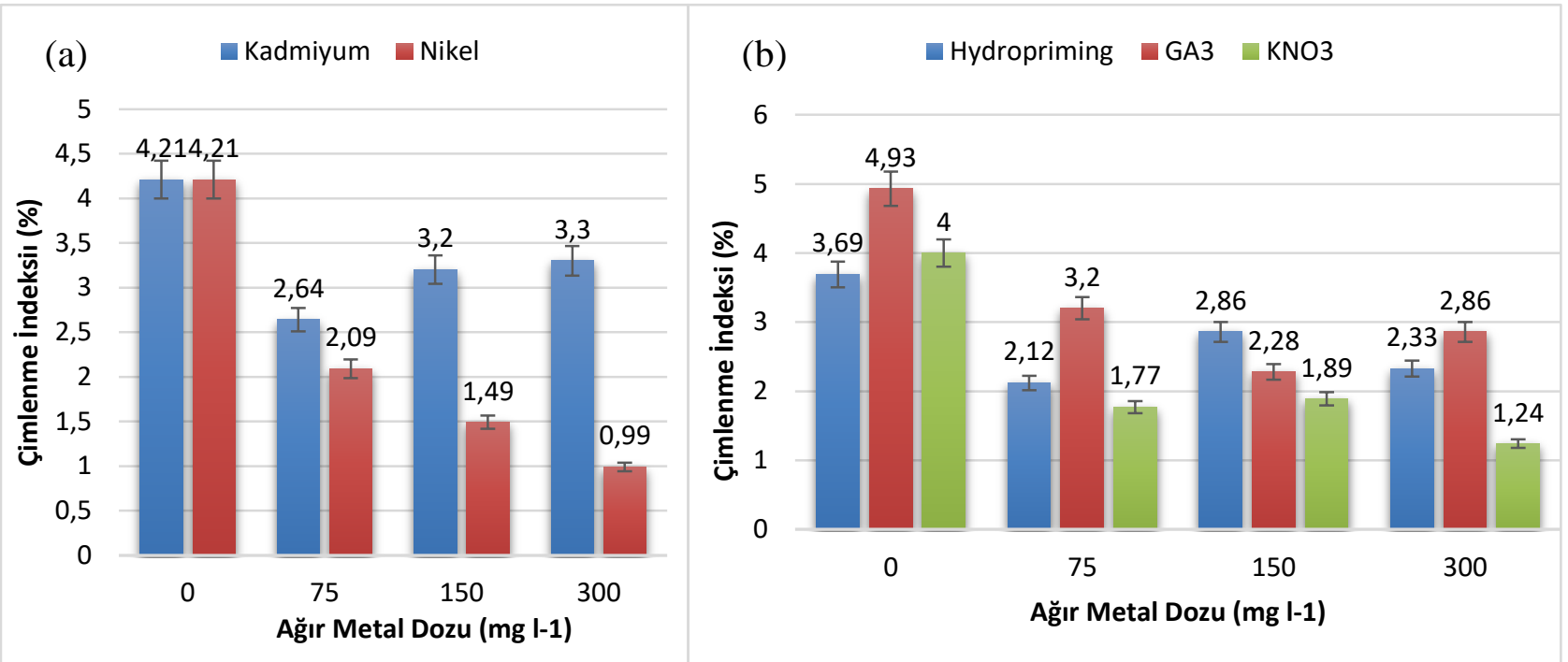

Şekil 2. Çimlenme indeksi üzerine a) ağır metal türü x ağır metal dozu ve b) ağır metal dozu x priming interaksiyonlarının etkisi.

\subsection{Ortalama Çimlenme Süresi}

Ağır metal türlerine bağlı olarak ortalama çimlenme süreleri önemli farkl1l1klar göstermiştir (Tablo 1). Kadmiyum uygulamasi sonucu belirlenen ortalama çimlenme süresi değeri 3.41 gün olurken, nikel uygulamasinda belirlenen ortalama çimlenme süresi 4.15 gün olarak tespit edilmiştir (Tablo 2). Bu durum nikelin kırmızı yumağın çimlenmesini kadmiyumdan daha fazla geciktirdiğini göstermektedir. Çalışkan (2009) farklı sebze türleri üzerinde yaptığı araştırmada ağır metallerin tohumların çimlenmesini geciktirdiğini, ancak bu etkinin bitki türüne, ağır metal türüne ve uygulanan doza bağlı olarak farkl1lıklar gösterebildiğini bildirmiştir.

Priming uygulamaları ortalama çimlenme süresi üzerinde önemli farklılıklar oluşmasına neden olmuştur (Tablo 1). $\mathrm{GA}_{3}$ uygulamasında ortalama çimlenme süresi 3.33 günle en hızlı çimlenmeyi sağlarken diğer iki uygulamadan istatistiksel olarak daha hızlı çimlenmeyi sağlamıştır. Hydropriming uygulamasinda belirlenen ortalama çimlenme süresi 3.88 gün ile $\mathrm{KNO}_{3}$ uygulamasında belirlenen ortalama çimlenme süresi (4.13 gün) istatistiksel olarak benzer grupta yer almıştır (Tablo 2). $\mathrm{Bu}$ durum $\mathrm{GA}_{3}$ uygulamasının kadmiyum ve nikel stresi altında kırmızı yumağın çimlenme süresi açısından diğer teşvik edicilerden daha etkili olduğunu göstermektedir. Priming ön uygulamalarına tabi tutulan tohumların çimlenme sürelerine ve özelliklerine bu uygulamaların etkileri, türlere ve koşullara bağlı olarak farklılık gösterebilmektedir. Nitekim Galhaut vd. (2014) uyarıcı uygulamaların ağır metalle bulaşık topraklarda kontrole göre önemli avantajlar sağladığını, bulaşık olmayan topraklarda bir farklılık oluşturmadığını ve kullanılan priming ajanlarının etkisinin de farklı olduğunu bildirmişlerdir.

Ağır metal dozlarına bağlı olarak kırmızı yumağın ortalama çimlenme süreleri 3.07 gün ile 4.45 gün arasında değişiklik göstermiştir. En hızlı çimlenme ağır metalin bulunmadığı kontrol uygulamasında gerçekleşirken, bu uygulama istatistiksel olarak ağır metal stresinin bulunduğu tüm uygulamalardan farklı bir grupta yer almıştır. $75 \mathrm{mg} \mathrm{l}^{-1}$ ağır metal uygulamasında belirlenen 
ortalama çimlenme süresi $150 \mathrm{mg} \mathrm{l}^{-1}$ dozunda belirlenen değerden önemli derecede kısa olurken, $300 \mathrm{mg} \mathrm{l}^{-1}$ dozunda belirlenen değerle istatistiksel olarak benzer grupta yer almıştır. 150 ve $300 \mathrm{mg} \mathrm{l}^{-}$ 1 ağır metal dozlarında belirlenen değerler ise istatistiksel olarak farksız olmuştur (Tablo 2). Bu durum ağır metallerin ortalama çimlenme süresini artırdığını bildiren Çalışkan (2009) ile Akıncı ve Akıncı (2011)'in bulguları ile uyuşmaktadır.

\subsection{Kök Uzunluğu}

Kök uzunluğu değerlerine ait varyans analiz sonuçları metal türü, metal dozu ile metal türü $\mathrm{x}$ metal dozu, metal dozu $\mathrm{x}$ priming interaksiyonlarının \%1 düzeyinde önemli etkiye sahip olduğu göstermiştir. Priming uygulaması ile diğer faktör interaksiyonlarının kırmızı yumakta kök uzunluğu üzerindeki etkisi ise istatistiksel olarak önemsiz bulunmuştur (Tablo 1).

Kök uzunluğu değeri kadmiyum uygulamasında $5.79 \mathrm{~mm}$ ile nikel uygulamasında belirlenen kök uzunluğu değerinden $(4.63 \mathrm{~mm})$ önemli derecede yüksek olmuştur. Bu durum kırmızı yumağın kök uzunluğunun çimlenme döneminde nikelden daha fazla etkilendiğini göstermektedir (Tablo 2). Benzer şekilde farklı bitkilerde nikel ve kadmiyumun etkilerini araştıran Peralta-Videa vd. (2004) ve Houshmandfar ve Moraghebi (2010) nikelin bitki fideleri üzerindeki ölümcül etkilerinin kadmiyumdan daha fazla olduğunu bildirmişlerdir.

Ağır metal uygulamalarının tamamı kontrole göre kök uzunluklarını önemli derecede azaltmıştır. Metal dozlarına bağlı olarak kök uzunlukları 2.74 $\mathrm{mm}$ ile $10.05 \mathrm{~mm}$ arasında değişmiştir (Tablo 2). En yüksek kök uzunluğu kontrol uygulamasında belirlenirken, bu uygulamada belirlenen değer istatistiksel olarak diğer tüm uygulamalardan daha yüksek değere sahip olurken, artan dozlara bağlı olarak kök uzunluğu azalmıştır. $75 \mathrm{mg} \mathrm{l}^{-1}$ metal dozu uygulamasında elde edilen kök uzunluğu değeri $150 \mathrm{mg} \mathrm{l}^{-1}$ ve $300 \mathrm{mg} \mathrm{l}^{-1}$ uygulamalarından istatistiksel olarak daha yüksek olurken, en yüksek dozlar olan 150 ve $300 \mathrm{mg}^{-1}$ dozları istatistiksel olarak birbirinden farksız olmuştur. Bulgularımıza paralel olarak nikel ve kadmiyumun kök gelişimi üzerindeki olumsuz etkileri diğer araştırıcılar tarafindan da bildirilmiştir (Erdoğan, 2005; Muhammad vd., 2008; Akınc1 ve Akınc1, 2011; Shao vd., 2011).

Priming uygulamalarına bağlı olarak kök uzunlukları $5.07 \mathrm{~mm}$ ile $5.40 \mathrm{~mm}$ arasında değişim göstermiştir. $\mathrm{KNO}_{3}$ uygulamasında belirlenen değer $(5.40 \mathrm{~mm})$ ilk sırada yer alırken, bunu sirasiyla hydropriming ve $\mathrm{GA}_{3}$ uygulamaları izlemiş, ancak bu farklılık istatistiksel olarak farksız olmuştur (Tablo 1,2).

Metal türü $\mathrm{x}$ metal dozu interaksiyonu sonucu belirlenen kök uzunluğu değerleri ve oluşan gruplar Şekil 3a'da verilmiştir. Şekil 3a'da izlendiği gibi, kontrol uygulamasında belirlenen kök uzunluğu değeri her iki metal türünün tüm dozlarında belirlenen kök uzunluğu değerlerinden istatistiksel olarak yüksek bulunmuştur. Genel olarak kadmiyum uygulanan bitkilerin kök uzunluğu nikel uygulananlara göre daha uzun olmuştur. Kadmiyum uygulamalarında kontrolden itibaren her artan doz için kademeli ve istatistiksel olarak önemli düşüşler meydana gelmiş ve her kadmiyum dozu ayrı bir grupta yer almıştır. Nikel stresine maruz kalan tohumların çimlenmesi ise kontrole göre önemli bir düşüş göstermiş, ancak nikel dozları kendi içerisinde istatistiksel olarak benzer grupta yer almıştır. $\mathrm{Bu}$ durum nikelin düşük dozlardan itibaren kırmızı yumağın kök uzaması üzerinde oldukça toksik etkiler gösterdiğini ortaya koymaktadır.

İstatistiksel açıdan önemli bulunan metal dozu x priming ikili interaksiyonunun kök uzunluğu üzerine etkileri incelendiğinde, ortalama kök uzunluğu değerleri $2.51 \mathrm{~mm}$ ile $11.00 \mathrm{~mm}$ arasında değişim göstermiştir. Ağır metal uygulamas1 yapılmayan kontrol uygulamalarında daha yüksek kök uzunluğu değerleri elde edilirken artan metal dozları ile birlikte kök uzunluğu değerleri düşmüş̧ür. Ağır metal uygulanmayan kontrol uygulamalarında $\mathrm{KNO}_{3}$ ve Hydropriming uygulamalarında belirlenen kök uzunluğu değerleri, $\mathrm{GA}_{3}$ uygulamasına göre daha yüksek bulunmuştur. $75 \mathrm{mg} \mathrm{l}^{-1}$ ağır metal dozunda ise $\mathrm{GA}_{3}$ uygulamasında belirlenen değer $\mathrm{KNO}_{3}$ uygulamasında belirlenen değerden istatistiksel olarak daha düşük olurken hydropriming uygulaması ile aynı grupta yer almıştır (Şekil 3b).

Ağır metal dozunun $150 \mathrm{mg} \mathrm{l}^{-1}$ ye çıkması ile $\mathrm{GA}_{3}$ ve $\mathrm{KNO}_{3}$ uygulamalarının kök uzunluğu üzerinde ağır metallerin oluşturduğu stresi hydropriming uygulamasına göre daha iyi baskıladığ 1 görülmektedir. $300 \mathrm{mg} \mathrm{l}^{-1}$ ağır metal dozunda ise her üç ön uygulamanın da benzer etkiler gösterdiği görülmektedir. Bu durum, ağır metal stersi altındaki kırmızı yumağın kök uzunluğu üzerinde priming ajanlarının etkisinin dozlara bağlı olarak farklılık gösterdiğini ortaya koymaktadır. Espanany vd. (2016), kadmiyum stresi altındaki çörekotu tohumlarında $\mathrm{KNO}_{3}$ ön uygulaması ile kök uzunluğunda kontrole göre 
önemli artışlar olduğunu, ancak bitkinin fide gelişimi üzerine kadmiyumun olumsuz etkilerinin ortadan kaldırılmasında salisilik asit ön muamelesinin daha etkili olduğunu bildirmişlerdir. Ağır metal varlığında farklı bitkilerde priming uygulamaları ile kök uzunluklarının olumlu yönde etkilendiği diğer araştırıcılar tarafindan da bildirilmiştir (Qaisar vd., 2014; Shinwari vd., 2015; Moulick vd., 2016; Kumar vd. 2016).

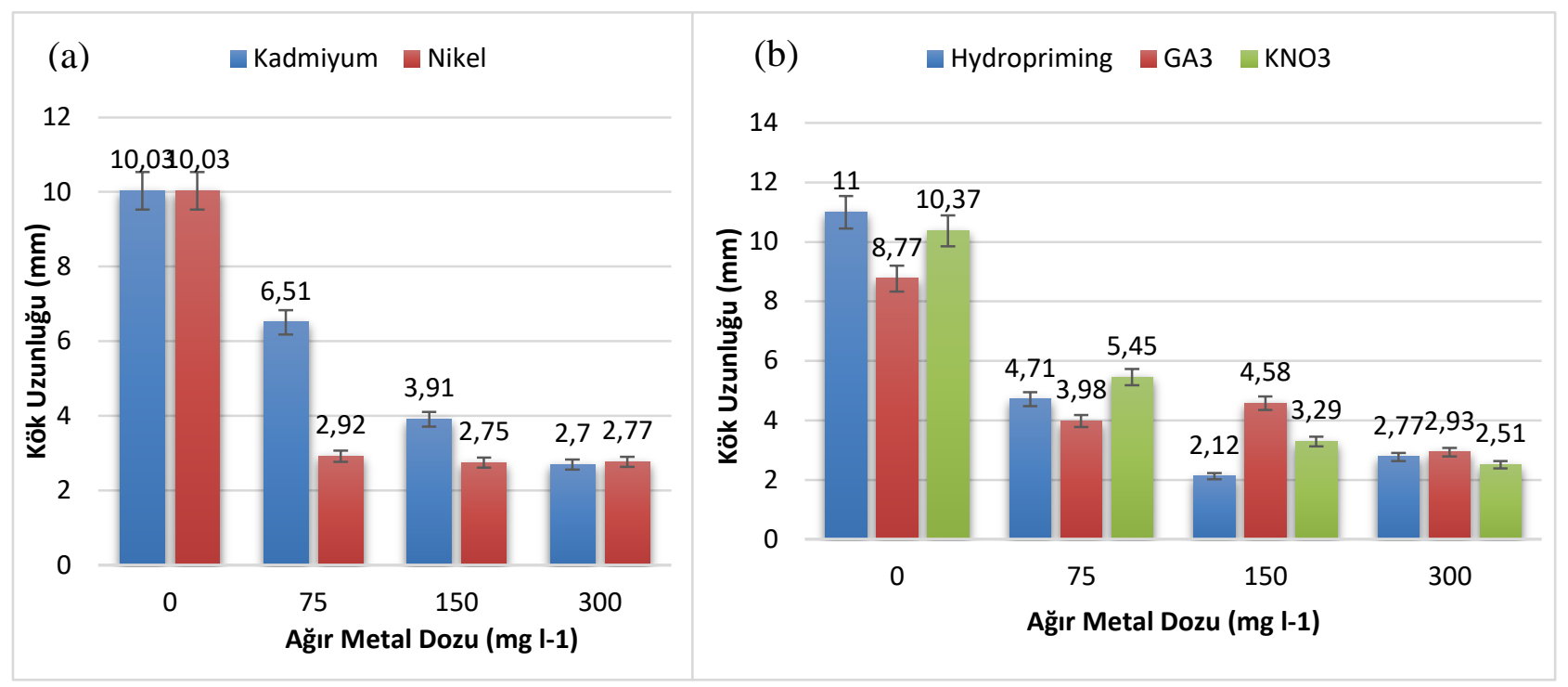

Şekil 3. Kök uzunluğu üzerine a) ağır metal türü x ağır metal dozu ve b) ağır metal dozu x priming interaksiyonlarının etkisi.

\subsection{Fide Uzunluğu}

Ağır metal türlerine bağlı olarak fide uzunluklarında istatistiksel olarak önemli farklılıklar meydana gelmemiştir. Kadmiyum uygulaması sonucu belirlenen fide uzunluğu değeri $25.46 \mathrm{~mm}$ olurken, nikel uygulamasında belirlenen ortalama fide uzunluğu değeri 24.25 mm olarak gerçekleşmiştir (Tablo 1, 2).

Artan ağır metal dozlarına bağlı olarak fide uzunluklarında önemli azalmalar tespit edilmiş ve her bir doz istatistiksel olarak farklı bir grupta yer almıştır. Belirlenen fide uzunlukları 0,75, 150 ve $300 \mathrm{mg} \mathrm{l}^{-1}$ dozları için sırasıyla 32.57, 27.43, 22.79 ve $17.03 \mathrm{~mm}$ olarak saptanmıştır (Tablo 1 ). En yüksek doz olan $300 \mathrm{mg}^{-1}$ ağır metal uygulamas1 fide uzunluğunun kontrole göre \% 47.7 azalmasına neden olmuştur. Nikel ve kadmiyumun erken dönemde farklı bitki türlerinin fide gelişimi üzerindeki olumsuz etkileri diğer araştırıcılar tarafından da bildirilmiştir. $\mathrm{Bu}$ bulguların aksine Kalaycığlu (2005) 1sırgan bitkisinin boy uzunluğu üzerinde kadmiyumun olumsuz bir etki meydana getirmediğini bildirmiştir. $\mathrm{Bu}$ durum ağır metallerin etkisinin bitki türlerine göre farkl1lık gösterebileceğini ortaya koymaktadır.
Priming uygulamalarına bağlı olarak fide uzunlukları $23.27 \mathrm{~mm}$ ile $32.53 \mathrm{~mm}$ arasinda değişim göstermiş ve bu değişim istatistiksel anlamda önemli olmuştur (Tablo 1, 2). Priming uygulamalarından, $\mathrm{GA}_{3}$ uygulamasında belirlenen fide uzunluğu $32.53 \mathrm{~mm}$ ile ilk sirada yer alırken, bunu $23.27 \mathrm{~mm}$ ile $\mathrm{KNO}_{3}$ uygulaması takip etmiş ve hydropriming uygulamasinda belirlenen fide uzunluğu değeri $19.07 \mathrm{~mm}$ ile son sirada yer almıştır. Elde edilen sonuçlar fide gelişimi açısından özellikle $\mathrm{GA}_{3}$ 'ün iyi bir priming ajanı olduğunu göstermiştir. Benzer şekilde ağır metal varlı̆̆ında farklı priming ajanlarının etkisinin farklı olduğu diğer araştırıcilar tarafindan da bildirilmiştir (Espanany vd., 2016; Kumar vd., 2016).

\section{Sonuç ve Öneriler}

Araştırma sonuçları, artan ağır metal dozlarına bağlı olarak hem çimlenme hem de fide gelişim özelliklerinin olumsuz yönde etkilendiğini göstermiştir. Genel olarak iki metal türünün kırmızı yumağın çimlenme ve fide gelişimi üzerine etkisi değerlendirildiğinde nikelin olumsuz etkisinin kadmiyumdan daha fazla olduğu söylenebilir. Kırmızı yumak kök uzunluğu artan ağır metal dozlarından olumsuz yönde etkilenmiştir. Kırmızı yumak kök uzunluğu 
üzerine nikelin etkisi kadmiyumdan daha fazla olmuştur. Kök uzunluğu uyarıcı ön uygulamalarından ise etkilenmemiştir. Artan metal dozları ile birlikte fide uzunluğu değerleri de önemli derecede azalmıştır. Fide uzunluğundaki bu azalma $\mathrm{GA}_{3}$ uygulaması ile bir miktar engellenebilmiştir. $\mathrm{GA}_{3}$ uygulanan tohumlardan elde edilen fideler diğer ön uygulamalarda belirlenen değerlerden daha yüksek olmuştur. Kırmızı yumağın kök ve fide gelişimi açısından $\mathrm{GA}_{3}$ ve $\mathrm{KNO}_{3}$ 'ün belli ağır metal düzeyinde fayda sağlayabilmesine rağmen, tohumların çimlenme yetenekleri üzerinde özellikle 150 ve $300 \mathrm{mg} \mathrm{l}^{-1}$ ağır metal dozlarında etkinliğini koruyamadığ 1 ve hatta etkilerinin olumsuz olduğu görülmüş̧ür.

Priming ajanlarının çimlenme özellikleri üzerinde olumlu etkisinin olmaması nedeniyle, kadmiyum ve nikel ile bulaşık alanlarda yeterli çıkışın sağlanabilmesi için, ekonomik olarak değerlendirmesi yapıldıktan sonra, kullanılacak tohumluk miktarının arttırılması başarıyı arttırabilir. Bitkilerin farklı stres koşullarında farklı priming ajanlarına farklı tepkiler göstermesi nedeniyle, kırmızı yumağın nikel ve kadmiyumla bulaşık alanlarda çimlenme ve fide gelişiminin desteklenmesinde farklı priming ajanları ile çalışmaların devam etmesinde fayda vardır.

\section{Kaynaklar}

Açıkgöz, E. 1994. Çim Alanlar Yapım ve Bakım Tekniği, Çevre Ltd. Şti. Yayınları, No:4, Bursa, 203s.

Akıncı, S. ve Akınc1, İ.E. 2011. Nikelin Ispanakta (Spinacia oleracea) Çimlenme ve Bazı Fide Büyüme Parametreleri Üzerine Etkisi, Ekoloji, 20 (79),69-76.

Akıncı, S. ve Çalışkan, Ü. 2010. Kurşunun Bazı Yazlık Sebzelerde Tohum Çimlenmesi ve Tolerans Düzeyleri Üzerine Etkisi, Ekoloji, 19 (74), 164-172.

Avcıoğlu, R. 1997. Çim Tekniği (Yeşil Alanların Ekimi Dikimi Bakımı), Ege Üniversitesi Matbaası, İzmir, 271s.

Çalışkan, Ü. 2009. Bazı Önemli Yazlık Sebzelerin Çimlenme Aşamasında Cd, Cr, Ni ve Pb'a Tepkisi. Yüksek Lisans Tezi, Kahramanmaraş Sütçü İmam Üniversitesi Fen Bilimleri Enstitüsü. Kahramanmaraş, 69 s.
Duo, L.A., Gao, Y.B. ve Zhao, S.L., 2005. Heavy Metal Accumulation and Ecological Responses of Turfgrass to Rubbish Compost with EDTA Addition, Journal of Integrative Plant Biology, 47 (9),10471054.

Ellis, R.H. ve Roberts, E.H., 1980. Towards a Rational Basis for Seed Testing Seed Quality, in: Hebblethwaitei, P. (Ed), Seed Production, Butterworths, London, pp. 605635.

Erdoğan, O., 2005. Fasulye (Phaseolus vulgaris L.) Fidelerinde Nikel Toksitesinin Humik Asit İle Azaltılması Üzerine Bir Araştırma. Yüksek Lisans Tezi, Kahramanmaraş Sütçü İmam Üniversitesi Fen Bilimleri Enstitüsü. Kahramanmaraş, 36s.

Espanany, A., Fallah, S. ve Tadayyon, A., 2016. Seed Priming Improves Seed Germination and Reduces Oxidative Stress in Black Cumin (Nigella sativa) in Presence of Cadmium. Industrial Crops and Products, 79, 195-204.

Galhaut, L., Lespinay, A.De, Walker, D.J., Bernal, M.P., Correal, E. ve Lutts, S., 2014. Seed Priming of Trifolium repens L. Improved Germination and Early Seedling Growth on Heavy Metal-Contaminated Soil. Water Air Soil Pollution, 225, 1905.

Goyer, R. A., 1991. Toxic effects of metals. In: Caserett and Doull's Toxicology, in: Amdur, M.O., Doull, J., Klaassen, C.D. (Eds.), The Basic Science of Poisons, Pergamon Press, New York, pp. 623-680.

Houshmandfar, A. ve Moragebi, F., 2011. Effect of Mixed Cadmium, Copper, Nickel and Zinc on Seed Germination and Seedling Growth of Safflower. African Journal of Agricultural Research, 6 (6), 1463-1468.

Houshmandfar, A. ve Moraghebi, F., 2010. Evaluation of Heavy Metal Tolerance at Different Clover Plant Growth Stages. Iranian Journal of Plant Physiology, 1 (2), 95-99.

Kabir, M., Iqbal, M.Z., Muhammad, M. ve Farooqi, Z.R., 2008. Reduction in Germination and Seedling Growth of Thespesia populnea L., Caused by Lead 
and Cadmium Treatments. Pakistan Journal of Botany, 40 (6), 2419-2426.

Kalaycioğlu, S., 2005. Isırgan (Urtica dioica L.) Bitkisinde Bazı Ağır Metallerin Büyüme Parametreleri Üzerine Etkilerinin Araştırılması. Yüksek Lisans Tezi, Marmara Üniversitesi Fen Bilimleri Enstitüsü. İstanbul, 57s.

Khan A.A., 1992. Preplant physiological seed conditioning. Horticultural Reviews, 14, 131-181.

Kırbağ-Zengin, F. ve Munzuroğlu, Ö., 2003. Fasulye Fidelerinin (Phaseolus vulgaris L.) Kök, Gövde ve Yaprak Büyümesi Üzerine $\operatorname{Kadmiyum}\left(\mathrm{Cd}^{++}\right)$ve Civa $\left(\mathrm{Hg}^{++}\right)^{\prime}$ nın Etkileri. Cumhuriyet Üniversitesi FenEdebiyat Fakültesi Fen Bilimleri Dergisi, 24 (1), 64-75.

Kumar, M., Pant, B., Mondal, S. ve Bose, B., 2016. Hydro and Halo Priming: Influenced Germination Responses in Wheat VarHUW-468 Under Heavy Metal Stress. Acta Physiologiae Plantarum, 38, 217.

Lyons-Alcantara, M., Tarazona J.V. ve Mothersill C., 1996. The Differential Effect of Cadmium Exposure on the Growth and Survival of Primary and Established Cells from Fish and Mammals. Cell Biology and Toxicology, 12, 29-38.

Marschner, H., 1995. Mineral Nutrition of Higher Plants: London, Academic Press, 889 p.

Mavi, K., Ermiş, S. ve Demir, İ., 2006 The Effect of Priming on Tomato Rootstock Seeds in Relation to Seedling Growth. Asian Journal of Plant Sciences, 5 (6), 940-947.

Mavi, K., Karaca, F. ve Yetişir, H., 2010. Effects of Different Priming Techniques on Germination and Seedling Emergence in Naturally Aged Melon Seeds, VIII. Sebze Tarımı Sempozyumu Bildirileri, Haziran 2010, Van, Türkiye, s.273-277.

Moulick, D., Ghosh, D. ve Chandra Santra, S., 2016. Evaluation of Effectiveness of Seed Priming with Selenium in Rice During Germination Under Arsenic Stress. Plant Physiology and Biochemistry, 109, 571578.
Muhammad, S., Iqbal, M.Z. ve Mohammad, A., 2008. Effect of Lead and Cadmium on Germination and Seedling Growth of Leucaena leucocephala. Journal of Applied Science and Environmental Management, 12 (2), 61-66.

Okcu, M., Tozlu, E., Kumlay, A.M. ve Pehluvan, M., 2009. Ağır Metallerin Bitkiler Üzerine Etkileri. Alınteri, 17 (B), 14-26.

Patade, Y.V., Maya, K. ve Zakwan, A., 2011. Chemical Seed Priming as a Simple Technique to Impart Cold and Salt Stress Tolerance in Capsicum. Journal of Crop Improvement, 25, 497-503.

Peralta, J.R., Gardea-Torresdey, J.L., Tiemann, K.J., Gomez, E., Arteaga, S., Rascon, E. ve Parsons, J.G., 2001. Uptake and Effects of Five Heavy Metals on Seed Germination and Plant Growth in Alfalfa (Medicago sativa L.). Bulletin of Environmental Contamination and Toxicology, 66, 727734.

Peralta-Videa, J.R., de la Rosa, G., Gonzalez, J.H. ve Gardea-Torresdey, J. L., 2004. Effects of the Growth Stage on the Heavy Metal Tolerance of Alfalfa Plants. Advances in Environmental Research, 8 (3-4), 679-685.

Qaisar, A., Iqbal, S., Jabeen, K. ve Latif, S., 2014. Response of Maize to Hydrogen Peroxide Priming Under Chromium Stress. Mycopath, 12 (2), 123-127.

Shao, Y., Jiang, L., Zhang, D., Ma, L. ve Li, C., 2011. Effects of Arsenic, Cadmium and Lead on Growth and Respiratory Enzymes Activity in Wheat Seedlings. Journal of Agricultural Research, 6 (19), 4505-4512.

Shinwari, K.I., Jan, M., Shah, G., Khattak, S.R., Urehman, S., Daud, M.K. ve Jamil, M., 2015. Seed Priming with Salicylic Acid Induces Tolerance against Chromium (VI) Toxicity in Rice (Oryza sativa L.). Pakistan Journal of Botany, 47 (SI), 161-170.

Smiri, M., 2011. Effect of Cadmium on Germination, Growth, Redox and Oxidative Properties in Pisum sativum Seeds. Journal of Environmental Chemistry and Ecotoxicology, 3 (3), 52-59. 
Sneideris, L.C., Gavassi, M.A., Campos, M.L., D'amico-Damiao, V. ve Carvalho, R. F., 2015. Effects of Hormonal Priming on Seed Germination of Pigeon Pea under Cadmium Stress. Anais Da Academia Brasileira de Ciencias, 87 (3), 1847-1852.

Sung, Y., Cantliffe, D.J. ve Nagata, R. 1998. Using a Puncture Test to Identify the Role of Seed Coverings on Thermotolerant Lettuce Seed Germination. Journal of the American Society for Horticulture Science, 123, 1102-1106.
Wang, Y.R., Yu, L., Nan, Z.B. ve Liu, Y.L., 2004. Vigor Tests Used to Rank Seed Lot Quality and Predict Field Emergence in Four Forage Species. Crop Science, 44 (2), 535541.

Zornoza, P., Robles, S. ve Martin, N., 1999. Alleviation of Nickel Toxicity by Ammonium Supply to Sunflower Plants. Plant and Soil, 208, 221-22. 